\title{
ЗВ’ЯЗУВАЛЬНА ФУНКЦІЯ СИРОВАТКОВОГО АЛЬБУМІНУ ПРИ ГІПЕРТОНІЧНІЙ ХВОРОБІ, НЕАЛКОГОЛЬНОМУ СТЕАТОГЕПАТИТІ ТА ЦУКРОВОМУ ДІАБЕТІ 2 ТИПУ
}

Вступ. В останні роки зріс інтерес до досліджень зв'язувальної функції сироваткового альбуміну (ЗФСА) при різних патологічних станах. Однак ї̈ зміни при хронічних захворюваннях залишаються маловивченими. 3 огляду на існуючі докази впливу порушень транспортної функції сироваткового альбуміну на есрективність медикаментозного лікування, важливим є вивчення взаємозв'язків порушень ЗФСА з різними патологічними процесами, що супроводжуються тривалим медикаментозним лікуванням. Поміж таких захворювань інтерес викликають гіпертонічна хвороба (ГХ) та різноманітні пов'язані з нею коморбідні стани.

Мета дослідження - оцінити взаємозв'язки змін ЗФСА та показників фрункціонального стану печінки при ГХ у поєднанні із супутнім неалкогольним стеатогепатитом (НАСГ) і цукровим діабетом (ЦД) 2 типу та запропонувати медикаментозну корекцію виявлених змін.

Методи дослідження. Обстежено 3 групи пацієнтів із ГХ II стадії з 2-3 ступенями артеріальної гіпертензії. До 1-ї групи ввійшли 28 осіб без супутніх захворювань, до 2-ї- 48 пацієнтів із супутнім НАСГ, до 3-ї- 47 осіб із НАСГ та ЦД 2 типу. В свою чергу, 2-гу і 3-тю групи поділили на 2 підгрупи (А та Б). Хворі підгрупи А отримували базову терапію ГХ і додатково препарат "Антраль" по 1 таблетці 3 рази на добу протягом 60 днів, підгрупи Б - лише базову терапію ГХ. Усі хворі пройшли стандартне клінічне обстеження, а також у них досліджували ЗФСА та показники печінки: активність аланінамінотрансферази (АлАТ), аспартатамінотрансфрерази (АсАТ), гамма-глутамілтранспептидази (ГГТ), лужної фросфратази (ЛФ), показник тимолової проби (ТП) і вміст загального білірубіну в сироватці крові. Групу порівняння становили 25 практично здорових осіб.

Результати й обговорення. У сироватці крові пацієнтів 1-ї групи підвищились активність ГГТ, ЛФ, показники ТП і загального білірубіну, а також спостерігали позитивний кореляційний зв'язок середньої сили ЗФСА із загальним білірубіном. У 2-й групі мали місце зниження ЗФСА і зростання всіх досліджуваних показників, окрім того, відзначили негативні кореляції середньої сили ії з АсАТ та ЛФ. У З-й групі відмітили ще більш суттєве зниження ЗФСА і показників фрункції печінки, а також негативні кореляційні зв'язки середньої сили ЗФСА з АлАТ і ТП та сильний зв'язок із ЛФ. У хворих обох підгруп, яких лікували антралем, порівняно з підгрупами без використання гепатопротектора, зросла ЗФСА та зменшились рівні підвищених досліджуваних біохімічних показників і збільшилася сила кореляційних зв'язків ЗФСА з усіма показниками. Це може бути пов'язано з позитивним впливом антралю на фрункціональний стан печінки.

Висновок. Застосування антралю у пацієнтів із ГХ у поєднанні з НАСГ та з НАСГ і ЦД 2 типу призводить до покращення показника ЗФСА та функціонального стану печінки.

КЛЮЧОВІ СЛОВА: гіпертонічна хвороба; неалкогольний стеатогепатит; цукровий діабет 2 типу; зв'язувальна фрункція сироваткового альбуміну; антраль.

ВСТУП. Альбумін - найпоширеніший протеїн людського організму. В нормі його вміст становить близько 55 \% усіх протеїнів плазми крові. Завдяки особливостям структури він виконує багато фрункцій, серед яких - регуляція колоїдно-осмотичного тиску, транспортування різноманітних речовин, антиоксидантна дія, вплив на систему коагуляційного гомеостазу та ін. [1, 2]. Привертає увагу зв'язувальна фрункція сироваткового альбуміну (ЗФСА). Завдяки особливій ( Ю. Р. Дзьордзьо, С. М. Андрейчин, 2021. конфігурації цього протеїну молекула може зв'язуватися 3 жирними кислотами, гормонами, оксидом азоту, іонами кальцію та хлору. Крім того, альбумін транспортує багато синтетичних лікарських засобів. Порушення ЗФСА може призвести до зниження ефективності медикаментозного лікування [3, 4].

Взаємодія лікарських засобів із сироватковим альбуміном людини, як правило, посилює розподіл та біодоступність препарату залежно від конкретних фрармакокінетичних властивостей 
його молекули. Крім того, сироватковий альбумін людини відіграє важливу роль у фрармакокінетичній дії різноманітних лікарських засобів, включаючи період напіввиведення, регулювання есрективності препарату, зменшення його токсичності та поліпшення специфічної спрямованості [4].

Протягом останніх років зріс інтерес до досліджень ЗФСА при різних захворюваннях, зокрема печінки. 3 огляду на існуючі докази впливу порушень транспортної фуннкції сироваткового альбуміну на ефективність медикаментозного лікування, важливим є вивчення взаємозв'язків порушень ЗФСА з різними патологічними процесами, що супроводжуються тривалим медикаментозним лікуванням. Поміж таких захворювань інтерес викликають гіпертонічна хвороба (ГХ) та різноманітні пов'язані 3 нею коморбідні стани [5-7]. Серед поширених супутніх захворювань важливими $€$ ті, що можуть чинити як прямий, так і опосередкований вплив на синтез та фуннкцію альбуміну, а саме неалкогольний стеатогепатит (НАСГ) та цукровий діабет (ЦД) 2 типу. При НАСГ може знижуватися білковосинтезувальна фрункція печінки через надлишкове накопичення жиру в клітинах печінки, що призводить до ліпотоксичного впливу і запального ушкодження гепатоцитів. Цукровий діабет 2 типу посилює цей процес у зв'язку з розвитком інсулінорезистентності тканин. Окрім того, гіперглікемія сприяє процесам гліколізування сироваткового альбуміну, що зумовлює порушення його структури та, як наслідок, втрату фрункції [8-10].

Важливість проблеми ГХ важко переоцінити. На сьогодні це одна 3 найпоширеніших серцево-судинних хвороб у світі. Попри значний прогрес у розробці методів лікування даного захворювання, їх есрективність часто залишається низькою. Тому вивчення взаємозв'язків поєднаних із ГХ захворювань та патологічних змін гомеостазу i, відповідно, оптимізація лікування залишаються актуальними [11-13].

Мета дослідження - оцінити взаємозв'язки змін ЗФСА та показників функціонального стану печінки при ГХ у поєднанні із супутнім НАСГ і ЦД 2 типу та запропонувати медикаментозну корекцію виявлених змін.

МЕТОДИ ДОСЛІДЖЕННЯ. У дослідженні брали участь 123 пацієнти, які мали ГX II стадії 3 2-3 ступенями артеріальної гіпертензії в поєднанні 3 діастолічною серцевою недостатністю I-III ФК за NYHA. Ïх поділили на 3 групи.

До 1-ї групи ввійшли 28 осіб із ГХ без супутньої патології (12 чоловіків і 16 жінок) віком від 45 до 76 років, середній вік - $(60,71 \pm 1,95)$ року.
До 2-ї групи включено 48 пацієнтів, у яких було діагностовано ГХ із супутнім НАСГ (22 чоловіки та 26 жінок), віком від 46 до 78 років, середній вік - $(64,68 \pm 1,07)$ року. Цю групу, у свою чергу, поділили на 2 підгрупи: хворі підгрупи 2-А (27 осіб) отримували базову терапію ГХ та додатково препарат "Антраль" по 200 мг 3 рази на добу протягом 60 днів, підгрупи 2-Б (21 особа) лише базову терапію ГХ. До 3-ї групи ввійшли 47 пацієнтів, у яких ГХ поєднувалась із супутніми НАСГ і ЦД 2 типу (21 чоловік та 26 жінок), віком від 58 до 82 років, середній вік $(68,72 \pm 0,86)$ року. В цю групу було включено хворих на ЦД 2 типу середнього ступеня тяжкості у стадії субкомпенсації. Ії̈ також поділили на 2 підгрупи: пацієнти підгрупи 3-А (27 осіб) отримували, крім базового лікування ГХ та ЦД 2 типу, препарат "Антраль" по 200 мг 3 рази на добу впродовж 60 днів, підгрупи 3-Б (20 осіб) - тільки базову терапію ГX.

Тривалість ГХ у хворих становила від 6 до 25 років. У дослідження не включали пацієнтів із симптоматичною гіпертензією та які вживають алкоголь (понад 40 мл етанолу на тиждень для чоловіків і 20 мл для жінок), а також хворих, які мали на момент огляду або в анамнезі дані про гострий коронарний синдром, гостре порушення мозкового кровообігу, онкологічні захворювання, вірусні, медикаментозні та автоімунні гепатити, психічні розлади.

Усім пацієнтам встановили діагноз, і вони отримували лікування згідно з критеріями унісрікованого протоколу надання медичної допомоги хворим з артеріальною гіпертензією (наказ МО3 України від 24.05.2012 р. № 384) і рекомендаціями Європейської асоціації кардіологів (ESC).

Діагноз НАСГ було встановлено відповідно до рекомендацій унісрікованого клінічного протоколу первинної, вторинної (спеціалізованої) медичної допомоги "Неалкогольний стеатогепатит" (наказ МОЗ України від 06.11.2014 р. № 826), а також рекомендацій Європейської асоціації 3 вивчення печінки (EASL). Функціональний стан печінки досліджували за допомогою соноеластограсрії на апараті “Ultima SM-30" методом SWEI з визначенням жорсткості паренхіми печінки, яка становила в середньому 8,42 кПА у хворих із $\mathrm{HAC \Gamma}$.

Усі пацієнти із ЦД 2 типу мали встановлений діагноз і отримували лікування згідно з унісрікованим клінічним протоколом первинної, вторинної (спеціалізованої) медичної допомоги "Цукровий діабет, 2 тип" (наказ МОЗ України від 21.12.2012 p. № 1118).

У всіх обстежуваних визначали ЗФСА за методом С. І. Чагера [14]. Біохімічними метода- 
ми у сироватці крові досліджували активність аланінамінотрансорерази (АлАТ), аспартатамінотрансорерази (АсАТ), гамма-глутамілтранспептидази (ГГТ), лужної фроссратази (ЛФ), показник тимолової проби (ТП), вміст загального білірубіну.

Статистичний аналіз одержаних результатів проводили за допомогою пакета програми STATISTICA 10 та Microsoft Excel методом параметричної кореляції Пірсона. Кореляційну залежність вважали сильною при значенні $r=0,7-$ 0,99, середньою - при $\mathrm{r}=0,3-0,69$, слабкою - при $r=0,01-0,29$.

РЕЗУЛЬТАТИЙ ОБГОВОРЕННЯ. У КОНТРОЛЬній групі ЗФСА та досліджувані показники стану печінки, згідно з даними літератури, були в межах норми. При аналізі кореляційних зв'язків ЗФСА з показниками фрункції печінки виявлено статистично достовірний негативний кореляційний зв'язок середньої сили з рівнем активності АлАТ $(r=-0,40, p<0,05)$.

У групі пацієнтів із ГХ без супутньої патології величина ЗФСА, а також активність у сироватці крові АлАТ та АсАТ не відрізнялися від таких у здорових осіб ( $>0,05)$. Водночас виявлено підвищення активності ГГТ, ЛФ, показника ТП і вмісту загального білірубіну $(p<0,05)$, однак їх показники залишались у межах фрізіологічних норм. Кореляційний аналіз виявив позитивний зв'язок середньої сили ЗФСА з рівнем загального білірубіну $(r=0,39, p<0,05)$ та слабкий негативний кореляційний зв'язок між ЗФСА й активністю АлАТ ( $r=-0,26, p>0,05)$, АсАТ $(r=-0,13, p>0,05)$ та ЛФ ( $r=0,32, p>0,05)$, що статистично недостовірно (табл. 1).

У підгрупі 2-А (ГХ у поєднанні з НАСГ) до лікування антралем було встановлено істотне зниження ЗФСА і зростання всіх інших досліджуваних показників печінки. Виявлено негативні
Зв'язки середньої сили ЗФСА з активністю АсАТ $(r=-0,36, p<0,05)$ та ЛФ ( $r=-0,44, p<0,05)$, а також слабкі негативні зв'язки її з АлАТ, ГГТ, що були статистично недостовірними ( $p>0,05)$. Порівняно 3 контрольною групою коефіцієнт кореляції між ЗФСА й АсАТ змінився на негативний і став сильнішим, також посилився негативний коефіцієнт із ЛФ. Окрім того, мав місце позитивний кореляційний зв'язок слабкої сили ЗФСА з показником ТП та рівнем загального білірубіну, проте також статистично не достовірний $(p>0,05)$. Інші показники теж змінилися незначно. У підгрупі 2-Б спостерігали аналогічні зміни.

У групі хворих на ГХ у поєднанні з НАСГ та ЦД 2 типу в підгрупі 3-А до корекції спостерігали ще більш значне зниження ЗФСА і зростання біохімічних показників порівняно з контрольною групою $(p<0,05)$. При аналізі кореляційних зв'язків між ЗФСА і показниками печінки встановлено наявність негативних кореляційних зв'язків середньої сили з активністю АлАТ $(r=-0,43, p<0,05)$ та показником ТП ( $r=-0,52, p<0,01)$, окрім того, мав місце негативний кореляційний зв'язок високої сили з активністю ЛФ ( $r=-0,79, p<0,001)$. Також було виявлено слабкий позитивний зв'язок ЗФСА $з$ рівнем загального білірубіну $(r=0,19$, p>0,05), проте статистично не достовірний. Порівняно $з$ контрольною групою кореляційний зв'язок цієї функції з показником ТП змінився 3 позитивного середньої сили на негативний середньої сили і став сильнішим, а кореляційний зв'язок з активністю ЛФ змінився 3 негативного слабкої сили на негативний високої сили. У підгрупі 3-Б спостерігали подібні зміни. Однак дещо слабшим кореляційний зВ'язок був між ЗФСА й активністю АлАТ, ТП і ЛФ (табл. 2).

На тлі приймання антралю в підгрупі 2-А (ГХ у поєднанні з НАСГ) було виявлено нормалізацію ЗФСА і показника АлАТ та істотне зниження активності АсАТ і ЛФ порівняно $з$ підгрупою 2-Б

Таблиця 1 - Коефріцієнти кореляцій між зв'язувальною фрункцією сироваткового альбуміну та біохімічними показниками у пацієнтів з гіпертонічною хворобою в поєднанні 3 неалкогольним стеатогепатитом

\begin{tabular}{|c|c|c|c|c|c|c|}
\hline \multirow{4}{*}{ Показник } & \multicolumn{6}{|c|}{ Група } \\
\hline & \multirow{3}{*}{$\begin{array}{c}\text { контрольна } \\
(\mathrm{n}=25)\end{array}$} & \multirow{3}{*}{$\begin{array}{c}1 \text {-ша } \\
(\mathrm{n}=28)\end{array}$} & \multicolumn{4}{|c|}{ 2-гa $(n=48)$} \\
\hline & & & \multicolumn{2}{|c|}{$\begin{array}{c}\text { підгрупа 2-A } \\
(\mathrm{n}=27)\end{array}$} & \multicolumn{2}{|c|}{$\begin{array}{c}\text { підгрупа 2-Б } \\
(n=21)\end{array}$} \\
\hline & & & до лікування & $\begin{array}{c}\text { після } \\
\text { лікування }\end{array}$ & до лікування & $\begin{array}{c}\text { після } \\
\text { лікування }\end{array}$ \\
\hline АлАТ & $-0,40(p<0,05)$ & $-0,26(p>0,05)$ & $-0,21(p>0,05)$ & $-0,42(p<0,05)$ & $-0,36(p>0,05)$ & $-0,28(p>0,05)$ \\
\hline AcAT & $0,15(p>0,05)$ & $-0,13(p>0,05)$ & $-0,36(p<0,05)$ & $-0,55(p<0,01)$ & $-0,25(p>0,05)$ & $-0,09(p>0,05)$ \\
\hline ГГТ & $0,28(p>0,05)$ & $0,01(p>0,05)$ & $-0,12(p>0,05)$ & $-0,58(p<0,01)$ & $0,15(p>0,05)$ & $0,40(p>0,05)$ \\
\hline ТП & $0,31(p>0,05)$ & $-0,03(p>0,05)$ & $0,12(p>0,05)$ & $-0,38(p>0,05)$ & $-0,05(p>0,05)$ & $-0,20(p>0,05)$ \\
\hline ЛФ & $-0,08(p>0,05)$ & $-0,32(p>0,05)$ & $-0,44(p<0,05)$ & $-0,47(p<0,05)$ & $-0,37(p>0,05)$ & $-0,27(p>0,05)$ \\
\hline $\begin{array}{l}\text { Загальний } \\
\text { білірубін }\end{array}$ & $0,17(p>0,05)$ & $0,39(p<0,05)$ & $0,11(p>0,05)$ & $-0,20(p>0,05)$ & $0,06(p>0,05)$ & $-0,02(p>0,05)$ \\
\hline
\end{tabular}

Примітка. Тут і в таблиці 2: p - достовірність коесріцієнта кореляції $(p<0,05-p<0,01)$. 
Таблиця 2 - Коефіцієнти кореляцій між зв'язувальною фрункцією сироваткового альбуміну та біохімічними показниками у пацієнтів 3 гіпертонічною хворобою в поєднанні 3 неалкогольним стеатогепатитом і цукровим діабетом 2 типу

\begin{tabular}{|c|c|c|c|c|c|}
\hline \multirow{4}{*}{ Показник } & \multicolumn{5}{|c|}{ Група } \\
\hline & \multirow{3}{*}{ контрольна } & \multicolumn{4}{|c|}{ 3-тя $(\mathrm{n}=47)$} \\
\hline & & \multicolumn{2}{|c|}{$\begin{array}{l}\text { підгрупа 3-A } \\
(n=27)\end{array}$} & \multicolumn{2}{|c|}{$\begin{array}{l}\text { підгрупа 3-Б } \\
(n=20)\end{array}$} \\
\hline & & до лікування & після лікування & до лікування & після лікування \\
\hline АлАТ & $-0,40(p<0,05)$ & $-0,43(p<0,05)$ & $-0,61(p<0,01)$ & $-0,08(p>0,05)$ & $-0,12(p>0,05)$ \\
\hline AcAT & $0,15(p>0,05)$ & $-0,06(p>0,05)$ & $-0,60(p<0,01)$ & $-0,12(p>0,05)$ & $-0,09(p>0,05)$ \\
\hline ГГТ & $0,28(p>0,05)$ & $0,08(p>0,05)$ & $-0,74(p<0,01)$ & $-0,18(p>0,05)$ & $-0,13(p>0,05)$ \\
\hline ТП & $0,31(p>0,05)$ & $-0,52(p<0,01)$ & $-0,68(p<0,001)$ & $-0,36(p>0,05)$ & $-0,24(p>0,05)$ \\
\hline ЛФ & $-0,08(p>0,05)$ & $-0,79(p<0,001)$ & $-0,71(p<0,001)$ & $-0,69(p<0,01)$ & $-0,66(p<0,01)$ \\
\hline Загальний білірубін & $0,17(p>0,05)$ & $0,19(p>0,05)$ & $-0,37(p>0,05)$ & $0,08(p>0,05)$ & $0,07(p>0,05)$ \\
\hline
\end{tabular}

$(p<0,05)$. Аналіз кореляційних зв'язків ЗФСА виявив негативний зв'язок середньої сили 3 активністю ГГТ (r=-0,58, p<0,01), який відрізнявся від такого в осіб без корекції, в яких цей зв'язок був позитивним. Також спостерігали негативні зв'язки середньої сили ЗФСА з активністю АлАТ $(r=-0,42, p<0,05)$, АсAТ $(r=-0,55, p<0,01)$ та ЛФ $(r=-0,47, p<0,05)$, причому ці зв'язки виявилися дещо сильнішими. У підгрупі 2-Б вищенаведені показники не зазнали істотних змін.

У підгрупі 3-А (ГХ у поєднанні з НАСГ і ЦД 2 типу) на тлі лікування відбулися істотне зростання ЗФСА та зниження всіх інших досліджуваних показників $(p<0,05)$, окрім АлАТ і ГГТ. У хворих, яким проводили корекцію антралем, виявлено сильні негативні зв'язки ЗФСА з показниками ГГТ $(r=-0,74, p<0,01)$ та ЛФ $(r=-0,71$, $p<0,001)$, а також негативні зв'язки середньої сили 3 активністю АлАТ ( $r=-0,61, p<0,01)$, АсАТ $(r=-0,60, p<0,01), T \Pi(r=-0,68, p<0,001)$ та рівнем загального білірубіну $(r=-0,37, p>0,05)$. Усі кореляції, крім вмісту загального білірубіну в сироватці крові, були статистично достовірними. Порівняно з підгрупою без корекції антралем кореляційні зв'язки з активністю АсАТ і ГГТ виявились суттєво сильнішими $(p<0,05)$. Посилення спостерігали також і за показниками АлАТ, ТП та вмістом загального білірубіну, однак менш суттєве. Кореляції між ЗФСА та показником ЛФ у хворих обох підгруп відрізнялися несуттєво. Кореляційні зв'язки у підгрупі 3-Б не зазнали суттєвих змін.

Вищенаведені дані можуть свідчити про наявність ураження гепатоцитів на тлі коморбідного патологічного процесу [15]. Застосування антралю $з$ метою корекції патологічних змін структури і фуннціонального стану печінки у Хворих на ГХ У поєднанні з НАСГ і ГХ з НАСГ та ЦД 2 типу супроводжувалось односпрямованим позитивним ефектом, що можна пояснити його позитивним впливом на печінку завдяки системній протизапальній дії цього препарату шляхом зниження синтезу медіаторів запалення, а також стабілізації ушкоджених мембран гепатоцитів та лізосомальних мембран. Окрім того, препарат має детоксикаційний вплив на весь організм та сприяє відновленню енергетичного метаболізму, в результаті чого покращується білковосинтезувальна срункція печінки $[16,17]$.

ВИСНОВКИ. 1. У хворих на ГХ без супутньої патології має місце незначне підвищення активності ГГТ, ЛФ, показника ТП і вмісту загального білірубіну в сироватці крові, а також поява статистично достовірного позитивного кореляційного зв'язку ЗФСА з рівнем загального білірубіну.

2. В осіб із ГХ у поєднанні з НАСГ відмічають зниження ЗФСА та підвищення активності АлАТ, АсАТ, ГГТ, ЛФ, показника ТП і вмісту загального білірубіну, а також появу негативних зв'язків між ЗФСА Й активністю АСАТ і ЛФ.

3. У хворих на ГХ у поєднанні з НАСГ та ЦД 2 типу відзначають ще більше порушення ЗФСА та підвищення активності АлАТ, АсАТ, ГГТ, ЛФ, показника ТП і вмісту загального білірубіну в сироватці крові. Крім того, має місце поява негативних кореляцій ЗФСА з показниками АлАТ, ТП і ЛФ.

4. На тлі лікування антралем у пацієнтів з $Г X$ із супутнім НАСГ спостерігають нормалізацію ЗФСА та показника АлАТ й істотне підвищення активності АсАТ і ЛФ. У хворих на ГХ із НАСГ і ЦД 2 типу виявлено відновлення ЗФСА та зниження активності АсАТ, ЛФ, показника ТП і вмісту загального білірубіну. Крім того, при обох коморбідних станах відмічають посилення кореляційних зв'язків ЗФСА з усіма досліджуваними показниками функції печінки.

Перспективи подальших досліджень. У подальшому планується дослідити шляхи корекції зв'язувальної фрункції сироваткового альбуміну при коморбідних захворюваннях, пов'язаних із гіпертонічною хворобою, а також розглянути можливості застосування їх у клінічній практиці. 


\section{СПИСОК ЛІТЕРАТУРИ}

1. Bernardi M. Role of human albumin in the management of complications of liver cirrhosi / M Bernardi, C. S Ricci, G. Zaccherini // Journal of clinical and experimental hepatology. - 2014. -4, No. 4. - P. 302-311.

2. Sleep D. Albumin as a versatile platform for drug half-life extension / D. Sleep, J. Cameron, L. R. Evans // Biochimica et Biophysica Acta (BBA)-General Subjects. 2013. - 1830, No.12. - P. 5526-5534.

3. Андрейчин С. М. Вплив глутаргіну на зв'язувальну фрункцію сироваткового альбуміну та інші показники фрункціонального стану печінки при гострому токсичному гідразиновому гепатиті / С. М. Андрейчин, 3. С. Скірак // Мед. та клініч. хімія. -2014. - 16, № 4. C. 66-69.

4. Fanali G. Human serum albumin: from bench to bedside / G. Fanali, A. Di Masi, V. Trezza [et al.] // Molecular Aspects of Medicine - 2012. - 33, No. 3. P. 209-290.

5. Захворюваність, поширеність та інвалідність унаслідок гіпертонічної хвороби: підходи до аналізу й прогнозування / І. В. Дроздова, А. А. Бабець, Л. Г. Степанова, Л. В. Омельницька // Укр. кардіол. журн. 2017. - № 1. - С. 85-93.

6. Лашкул 3. В. Особливості епідеміології артеріальної гіпертензії та її ускладнень на регіональному рівні з 1999 по 2013 роки / З. В. Лашкул // Сучасні мед. технології. - 2014. - № 2. - С. 134-141.

7. Пасієшвілі Л. М. Неалкогольна жирова хвороба печінки та артеріальна гіпертензія: патогенетичні чинники формування та прогресування / Л. М. Пасієшвілі, Н. М. Железнякова, Т. М. Пасієшвілі // Гастроентерологія. - 2014. - 52, № 2. - С. 46-49.

8. Руденко Т. М. Корекція проявів неалкогольного стеатогепатиту у хворих на артеріальну гіпертензію 3 ожирінням / Т. М. Руденко // Журн. клініч. та експерим. мед. дослідж. - 2013. - № 2. - С. 191-195.

\section{REFERENCES}

1. Bernardi, M., Ricci, C.S., \& Zaccherini, G. (2014). Role of human albumin in the management of complications of liver cirrhosis. Journal of Clinical and Experimental Hepatology, 4 (4), 302-311.

2. Sleep, D., Cameron, J., \& Evans, L.R. (2013). Albumin as a versatile platform for drug half-life extension. Biochimica et Biophysica Acta (BBA)-General Subjects, 1830 (12), 5526-5534.

3. Andreichyn, S.M., \& Skirak, Z.S. (2014). Effect of glutargine on serum albumin binding function and other indicators of liver function in acute toxic hydrazine hepatitis. Medical and Clinical Chemistry, 16 (4), 66-69 [in Ukrainian].

4. G. Fanali, A. Di Masi, V. Trezza (2012). Human serum albumin: from bench to bedside. Molecular Aspects of Medicine, 33 (3), 209-290.

5. Drozdova, I.V., Babets, A.A., Stepanova, L.H., \& Omelnytska, L.V. (2017). Morbidity, prevalence and disability due to hypertension: approaches to analysis and prediction. Ukrainian Journal of Cardiology, (1), 8593 [in Ukrainian].
9. Вдовиченко В. І. Гіпертонічна хвороба в поєднанні із цукровим діабетом 2 типу: суперечливість поглядів на тактику ведення / В. І. Вдовиченко, В. В. Кульчицький // Укр. тер. журн. - 2015. - № 1. C. $63-68$.

10. Радченко Л. М. Стан печінки у хворих на гіпертонічну хворобу та надлишкову масу тіла / Л. М. Радченко // Мед. гідрологія та реабілітація. 2009. - № 3. - C. 52-56.

11. Nonalcoholic fatty liver disease: an emerging driver of hypertension / Y. C. Zhao, G. J. Zhao, Z. Chen [et al.] // Hypertension. 2020. - 75, No. 2. - P. 275-284.

12. Степанов Ю. М. Клинические особенности течения неалкогольного стеатогепатита в зависимости от сопутствующих заболеваний / Ю. М. Степанов, А. Ю. Филиппова // Сучасна гастроентерологія. 2006. - 29, № 3. - С. 4-7.

13. Боднар Р. М. Неалкогольна жирова хвороба печінки у хворих на цукровий діабет типу 2: патогенез, діагностика та лікування / Р. М. Боднар // Ендокринологія. - 2012. - 17, № 1. - С. 94-101.

14. Скірак 3. С. Порушення зв'язувальної фрункції сироваткового альбуміну при токсичних гепатитах : дис. ... канд. мед. наук : 03.00.04 / Скірак Зіновій Семенович. - Тернопіль, 2016. - 161 с.

15. Кірієнко В. Т. Ефективність антралю у хворих на хронічний гепатит С / В. Т. Кірієнко, В.В.Потій // Вісн. наук. дослідж. - 2015. - № 3. - С. 28-30.

16. Звягинцева Т. Д. Применение препарата Антраль в лечении неалкогольного стеатогепатита: настоящее и будущее / Т. Д. Звягинцева, А. И. Чернобай // Человек и Лекарство - Казахстан. - 2016. - 17, № 78. - С. 84-90.

17. Борисов С. О. Детоксикаційний вплив препарату Антраль на перебіг обструктивної нефрропатії / С. О. Борисов, Ф.І.Костєв, О. В. Борисов // Здоровье мужчины. - 2013. - № 4. - С. 193.

6. Lashkul, Z.V. (2014). Features of the epidemiology of hypertension and its complications at the regional level from 1999 to 2013. Modern Medical Technologies, (2), 134-141 [in Ukrainian].

7. Pasiieshvili, L.M., Zhelezniakova, N.M., \& Pasiieshvili, T.M. (2014). Non-alcoholic fatty liver disease and hypertension: pathogenetic factors of formation and progression. Gastroenterology, 52 (2), 46-49 [in Ukrainian].

8. Rudenko, T.M. (2013). Correction of manifestations of nonalcoholic steatohepatitis in patients with hypertension and obesity. Journal of Clinical and Experimental Medical Research, (2), 191-195 [in Ukrainian].

9. Vdovychenko, V.I., \& Kulchytskyi, V.V. (2015). Hypertension in combination with type 2 diabetes mellitus: conflicting views on management tactics. Ukrainian Therapeutic Journal, (1), 63-68 [in Ukrainian].

10. Radchenko, L.M. (2009). Liver status in patients with hypertension and overweight. Medical Hydrology and Rehabilitation, (3), 52-56 [in Ukrainian].

11. Zhao, Y.C., Zhao, G.J., Chen, Z., She, Z.G., Cai, J., \& Li, H. (2020). Nonalcoholic fatty liver disease: 
an emerging driver of hypertension. Hypertension, 75 (2), 275-284.

12. Stepanov, Ju.M., \& Filippova, A.Ju. (2006). Clinical features of the course of non-alcoholic steatohepatitis depending on comorbidities. Modern Gastroenterology, 29 (3), 4-7 [in Russian].

13. Bodnar, P.M. (2012). Non-alcoholic fatty liver disease in patients with type 2 diabetes mellitus: pathogenesis, diagnosis and treatment. Endocrinology, 17 (1), 94-101 [in Ukrainian].

14. Skirak, Z.S. (2016). Disorder of serum albumin connective function during toxic hepatitis. Candidate's thesis. I. Horbachevsky Ternopil National Medical University. Ternopil [in Ukrainian].

15. Kiriienko, V.T., \& Potii, V.V. (2015). The effectiveness of antral in patients with chronic hepatitis C. Bulletin of Scientific Research, (3), 28-30 [in Ukrainian].

16. Zvjaginceva, T.D., \& Chernobaj, A.I. (2016). The use of the drug Antral in the treatment of non-alcoholic steatohepatitis: present and future. Kazahstan - Man and Medicine, 17 (78), 84-90 [in Russian].

17. Borysov, S.O., Kostiev, F.I., \& Borysov, O.V. (2013). Detoxifying effect of Antral on the course of obstructive nephropathy. Men's Health, (4), 193-193 [in Ukrainian].

Yu. R. Dzordzo, S. M. Andreychyn

I. HORBACHEVSKY TERNOPIL NATIONAL MEDICAL UNIVERSITY

\title{
THE BINDING FUNCTION OF SERUM ALBUMIN IN HYPERTENSION, NON-ALCOHOLIC STEATOHEPATITIS AND TYPE 2 DIABETES
}

\begin{abstract}
Summary
Introduction. In recent years, there has been a growing interest in studies of the binding function of serum albumin (BFSA) in various pathological conditions. However, changes in BFSA in chronic diseases remain poorly studied. Given the existing evidence of the impact of serum albumin transport disorders on the effectiveness of drug treatment, it is important to study the relationship of BFSA disorders with various pathological processes accompanied by long-term drug treatment. Among such diseases, hypertension (HTN) and various comorbid conditions arouse interest.
\end{abstract}

The aim of the study - to evaluate the relationships between changes in BFSA and indicators of liver function in HTN in combination with concomitant non-alcoholic steatohepatitis (NASH) and type 2 diabetes mellitus (DM) and to propose drug correction of the detected changes.

Research Methods. Three groups of patients with stage II HTN with a degree of arterial hypertension of 2-3 were examined. Group 1 included 28 patients without concomitant diseases, group 2 included 48 patients with concomitant $\mathrm{NASH}$, and group 3 included 47 people with NASH and type 2 diabetes. Groups 2 and 3, in turn, were divided into two subgroups ( $A$ and $B$ ). Patients of subgroup A - received basic HTN therapy and, in addition, the Antral drug of 1 tablet 3 times a day for 60 days, of subgroup B - only basic HTN therapy. All patients underwent a standard clinical examination, as well as had their BFSA and liver indicators inspected: the activity of alanine aminotransferase (ALT), aspartate aminotransferase (AST), gamma-glutamyltranspeptidase (GGT), alkaline phosphatase (ALP), thymol turbidity test (TTT) and total serum bilirubin (T Bil) in blood. The comparison group consisted of 25 practically healthy individuals.

Results and Discussion. Increased activity of GGT, ALP, TTT indicators and total serum bilirubin was observed in patients of group 1, and a positive correlation between the average strength of BFSA and total bilirubin was observed. In group 2 there was a decrease of BFSA and an increase of all the studied indicators, in addition, negative correlations of its average strength with AST and ALP were observed. Group 3 showed an even more significant decrease of BFSA and liver function indicators, as well as negative correlations of the average strength of BFSA with ALT and TTT and a strong connection with ALP. In patients of both subgroups treated with Antral, compared with the subgroups without the use of hepatoprotectant, BFSA increased and the studied increased levels of biochemical indicators decreased and the strength of correlations of BFSA with all indicators increased. This may be due to the positive effect of Antral on the functional state of the liver.

Conclusions. The use of Antral in patients with HTN in combination with NASH and NASH and type 2 DM leads to an improvement in the indicator of BFSA and liver function.

KEY WORDS: hypertension; non-alcoholic steatohepatitis; type 2 diabetes mellitus; binding function of serum albumin; Antral.

Адреса для листування: Ю. Р. Дзьордзьо, Тернопільський національний медичний університет імені І. Я. Горбачевського мОз України, майдан Волі, 1, Тернопіль, 46001, Україна, e-mail: dzordzo.yuriy@gmail.com. 